\title{
Immunostimulating and growth promoting activity of dietary levamisole on cirrhinus mrigala fingerlings
}

\begin{abstract}
The effects of supplementing diets with levamisole on growth, immune response and resistance against pathogenic Aeromonas hydrophila were determined. Fish were assigned to three treatments with different level of levamisole $\left(125,250\right.$ and $500 \mathrm{mg} \mathrm{kg}^{-1}$ diet) and the control diet was prepared without levamisole. Cirrhinus mrigala were fed at $4 \%$ of their body mass for 60 days. Growth performance, enzyme activities and immunological parameters were analyzed among groups. The total erythrocyte count, total leucocyte count, phagocytic activity and NBT reduction were significantly $(\mathrm{P}<0.05)$ enhanced in levamisole treated group when compared to control. The relative percentage survival, $A$. hydrophila post-challenge was significantly higher in fishes fed on $250 \mathrm{mg} \mathrm{kg}^{-1}$ of levamisole supplemented diet. The same dose also resulted in significantly high specific growth rate (SGR), feed conversion ratio (FCR), apparent protein digestibility (APD) and elevated intestinal enzyme activities compared to other groups. Thus, administration of $250 \mathrm{mg}$ of levamisole $\mathrm{kg}^{-1}$ diet is recommended for enhancement of immunity, growth and survival of C. mrigala hence acting as a potent immunostimulant agent
\end{abstract}

Keywords: Aeromonas hydrophila, Mrigala, Enzyme activities, Growth performance, Immunological parameters
Volume 4 Issue 6 - 2016

Anita Bhatnagar, Ritu Lamba

Department of Zoology, Kurukshetra University, India

Correspondence: Anita Bhatnagar, Department of Zoology, Kurukshetra University, India, Tel 009 I-0 I 744-2384 I0; +9 I 09896634580,Email anitabhatnagar@gmail.com

Received: November 0I, 2016 | Published: December 28, 2016
Abbreviations: PR, Phagocytic Ratio; PI, Phagocytic Index; SGR, Specific Growth Rate; PER, Protein Efficiency Ratio; GCE, Gross Conversion Efficiency; APD, Apparent Protein Digestibility; FCR, Feed Conversion Ratio

\section{Introduction}

With increasing trend of searching different harmonic measures for preventing fish diseases, imunnostimulants are gaining popularity as an attractive and promising alternative to chemotherapeuants in aquaculture practices. Immunostimulants comprise a group of biological or synthetic substances known to stimulate the nonspecific immune mechanisms of host on their own or specific immune mechanism when conjugated with some antigen. It is well known that fish rely more profoundly on nonspecific defense mechanism than mammals. ${ }^{1}$ Immunostimulants elicit an effective and profound immune response to those infectious agents such as viruses, bacteria, fungi, and parasites without risks of toxicity, carcinogenicity or tissue residues. ${ }^{2}$ Hence, immunostimulants as dietary additives appears to be a valuable possibility in enhancing disease resistance of fishes.

Levamisole- a synthetic phenylimidazolthiazole, is an antihelminthic drug which has been widely in use for the treatment of nematode infections in man and animals. Incidental observations implied that upon treatment with levamisole a state of enhanced resistance to various kinds of infection was achieved. The ability of this agent to positively regulate the immune response of both healthy ${ }^{3}$ and immunocompromised individuals is well documented. ${ }^{4-6}$ It was the first drug reported to enhance various aspects of cellular immunity among healthy laboratory animals. ${ }^{3}$ In fish, levamisole has been used in various studies with the intention of enhancing the nonspecific immune response $\mathrm{e}^{7-12}$ or as an adjuvant with a vaccine. ${ }^{13,14}$ Its action has been reported in several studies as: modulation of T-cell function, cytotoxic activity of leucocytes, enhanced phagocytosis and respiratory burst and activation of macrophage-activating factor. Besides imparting immunity, it's capability of enhancing resistance to pathogenic bacteria in several fish species have been reported. ${ }^{10}$
Alongside the immunostimulating influence and potential use in fish health management, the role of levamisole role in growth promotion and digestibility is also well documented.${ }^{15}$ Hence, further expedition on the possible effect of dietary administration of levamisole on fish growth; digestibility, immunity and resistance against pathogens need to be determined. Present study aims to assess the growth, biochemical parameters, water quality, immune response and disease resistance of Cirrhinus mrigala (average weight of $1.68 \pm 0.04 \mathrm{~g}$ ) fed on diet containing different concentration of levamisole under laboratory conditions.

\section{Materials and methods}

\section{Fish and rearing conditions}

The experimental Cirrhinus mrigala were collected from a local fish farm (Jasbeer fish seed farm, Adon, Kurukshetra, India). The fish were stocked in a re-circulating water tubs and acclimatized to the ambient laboratory condition. The fish were fed with basal diet for 10 days, prior to starting the experiment.

\section{Experimental diets}

A basic diet with $40 \%$ protein and about $9.10 \%$ fat was prepared that contained ground nut oil cake 650 , rice bran 42 , hydrothermically processed soybean 266, wheat flour 32, mineral mixture 10 (in $\mathrm{kg}$ g-1) which was considered the control diet. Levamisole was procured from Rowan Bioceuticals Private Limited, New Delhi. In processed soybean based feed, powdered levamisole was added @ $125 \mathrm{mg}$ for diet L1, $250 \mathrm{mg}$ for treatment L2 and $500 \mathrm{mg}$ for treatment L3 (See Table 1 for proximate composition of ingredients). Diet with no levamisole served as the control diet (LC). All dietary ingredients were mixed thoroughly by adding warm distilled water and homogeneous dough was prepared. The resulting dough was passed through a mincer to produce feed pellets of $0.5 \mathrm{~mm}$ in diameter. Then, pellets were first air dried and packed in airtight containers. The diets were kept in a refrigerator at $4^{\circ} \mathrm{C}$ until use. All these diets were isocaloric and isoproteic with approximately $40 \%$ proteins (Table 2 ). 
Table I Proximate composition of different ingredients used in experimental feeds for Cirrhinus mrigala

\begin{tabular}{|c|c|c|c|c|c|c|c|}
\hline Ingredients & $\begin{array}{l}\text { Crude } \\
\text { protein (\%) }\end{array}$ & Crude fat (\%) & Crude fiber (\%) & Ash (\%) & Moisture(\%) & NFE (\%) & Gross energy $\left(\mathrm{kJg}^{-1}\right)$ \\
\hline Soybean & $43.53 \pm 0.19$ & $15.86 \pm 0.18$ & $6.5 I \pm 0.02$ & $6.83 \pm 0.02$ & $6.06 \pm 0.53$ & $23.22 \pm 2.34$ & $19.54 \pm 2.78$ \\
\hline Rice Bran & $12.18 \pm 0.23$ & $10.17 \pm 0.01$ & $16.64 \pm 0.04$ & $10.48 \pm 0.09$ & $8.68 \pm 0.37$ & $41.65 \pm 3.66$ & $14.04 \pm 1.02$ \\
\hline Wheat Flour & II. $28 \pm 0.23$ & $4.46 \pm 0.03$ & $10.83 \pm 0.03$ & $7.76 \pm 0.8$ & $8.48 \pm 0.29$ & $57.19 \pm 5.17$ & $14.23 \pm 1.16$ \\
\hline $\begin{array}{l}\text { Groundnut } \\
\text { Oil Cake }\end{array}$ & $42.09 \pm 0.23$ & $5.68 \pm 0.04$ & $8.29 \pm 0.04$ & $5.97 \pm 0.03$ & $6.72 \pm 0.27$ & $31.25 \pm 3.25$ & $16.33 \pm 2.13$ \\
\hline
\end{tabular}

All values are Mean \pm S.E of mean

Table 2 The composition (\% dry weight basis) of experimental diets

\begin{tabular}{|c|c|c|c|c|}
\hline \multirow{2}{*}{$\begin{array}{l}\text { Proximate } \\
\text { analysis }\end{array}$} & \multicolumn{4}{|c|}{ Dietary treatments } \\
\hline & $\begin{array}{l}\text { LC } \\
\text { (control) }\end{array}$ & $\begin{array}{l}\text { LI } \\
\text { (I } 25 \mathrm{mg})\end{array}$ & $\begin{array}{l}\text { L2 } \\
(250 \mathrm{mg})\end{array}$ & $\begin{array}{l}\text { L3 } \\
(500 \mathrm{mg})\end{array}$ \\
\hline Crude protein ( \% ) & $39.85 \pm 1.36^{A}$ & $39.00 \pm 1.20^{\mathrm{A}}$ & $39.40 \pm 1.78^{A}$ & $38.80 \pm 1.95^{\mathrm{A}}$ \\
\hline Crude fat ( \% ) & $9.10 \pm 0.26^{\mathrm{B}}$ & $9.31 \pm 0.36^{A}$ & $9.35 \pm 0.05^{A}$ & $9.28 \pm 0.13^{A}$ \\
\hline Crude fiber (\%) & $6.23 \pm 0.06^{A}$ & $6.05 \pm 0.18^{B}$ & $6.26 \pm 0.2 \mathrm{I}^{\mathrm{A}}$ & $6.20 \pm 0.15^{\mathrm{A}}$ \\
\hline Total ash ( \% ) & $6.60 \pm 0.39 c$ & $6.80 \pm 0.33^{\mathrm{A}}$ & $6.76 \pm 0.13^{B}$ & $6.83 \pm 0.1 \mathrm{I}^{\mathrm{A}}$ \\
\hline Moisture ( \% ) & $7.4 I \pm 0.20^{A}$ & $7.35 \pm 0.5^{\mathrm{B}}$ & $7.40 \pm 0.66^{\mathrm{A}}$ & $7.46 \pm 0.29^{A}$ \\
\hline Nitrogen free extract (\% ) & $29.30 \pm 1.42^{B}$ & $31.40 \pm 1.74^{\mathrm{A}}$ & $30.80 \pm 2.69^{\mathrm{AB}}$ & $31.40 \pm 1.79^{\mathrm{A}}$ \\
\hline Gross energy $\left(\mathrm{kJ} \mathrm{g}^{-1}\right)$ & $17.93 \pm 0.09^{A}$ & $18.30 \pm 0.12^{\mathrm{A}}$ & $18.29 \pm 0.06^{A}$ & $18.23 \pm 0.20^{A}$ \\
\hline Feed phosphorus (\%) & $1.34 \pm 0.07^{\mathrm{B}}$ & $1.33 \pm 0.03^{\mathrm{B}}$ & $1.38 \pm 0.09^{A}$ & $1.42 \pm 0.07^{\mathrm{A}}$ \\
\hline
\end{tabular}

Means with different letters in the same row are significantly $(P<0.05)$ different.

(Data were analyzed by Duncan's Multiple Range test)

\section{Experimental design}

All dietary treatment groups were performed with triplicate of each. The experiment was conducted under laboratory conditions $\left(25 \pm 1^{\circ} \mathrm{C}\right)$ in plastic tubs $(30 \mathrm{~L}$ capacity). Each tub was filled with dechlorinated tap water and then stocked with 20 advanced fish fry with average body weight of $1.68 \pm 0.04 \mathrm{~g}$. All groups of fish were fed daily at 4\% Body Weight (BW) in 2 instalments at 08:00 and 16:30 hours for 60 days with constant aeration and daily two-thirds water exchange. Individual weights of fish were recorded at the beginning and end of experiment and at every 15 th day of interval with the help of top pan balance. Length of fish was measured using a simple centimeter scale. Initial and final fish samples were processed for proximate analysis following Association of Official Analytical Chemists. ${ }^{16}$

Proximate analysis of experimental diets (Table 1) and fish carcass (initial and final) was done following the standard methods of the AOAC. ${ }^{16}$ Chromic oxide levels in the diets as well as in the faecal samples were estimated spectrophotometrically. ${ }^{17}$ The intact pellets were picked up by tube dropper or siphon pipe and dried in oven in a petridish.

Apparent protein digestibility (APD) of the diets was calculated according to the methods of Cho et al. ${ }^{18}$ It was determined by an indirect method, using chromic oxide as a dietary inert external marker. As a dietary inert substance, chromic oxide $\left(\mathrm{Cr}_{2} \mathrm{O}_{3}\right)$ is excreted without digestion or loss. Chromic oxide was incorporated into the diet and faecal samples were collected after a minimum period of feeding, normally 14 days. $100 \mathrm{mg}$ of faecal samples and diet were assayed for $\mathrm{Cr}_{2} \mathrm{O}_{3}$ and the percentage dry matter digestibility was calculated according to Cho et al. ${ }^{18}$ Live weight gain (g), percent weight gain (PWG), specific growth rate (SGR), feed consumption per day in percentage of body weight, feed conversion ratio (FCR), gross conversion efficiency (GCE), and protein efficiency ratio (PER) were calculated using standard method. ${ }^{19}$ At the termination of experiment, from each treatment, six fish were randomly sampled and kept on ice to remove the intestines which were processed for the determination of enzyme activity of protease, ${ }^{20}$ amylase, ${ }^{21}$ and cellulose. ${ }^{22}$

During the experiment, the water samples from all the tubs were collected fortnightly and temperature, dissolved oxygen (DO), $\mathrm{pH}$, electrical conductivity, calcium, chlorides and total alkalinity were measured following American Public Health Association ${ }^{23}$ to investigate the influence of supplemented feeds on quality of holding water. At the end of feeding trials, water samples from each tub were collected at two- hour intervals for the estimation of excretory levels of total ammonia (N-NH4+) and reactive orthophosphate following the APHA, ${ }^{23}$ and calculated following Sumagaysay-Chavoso. ${ }^{24}$

\section{Collection of blood Samples}

Blood samples were collected from caudal vein. Blood samples of five fishes were pooled for analysis.. EDTA $\left(1 \mathrm{mg}^{\mathrm{EDTA} \mathrm{m} \mathrm{l}^{-1}}\right)$ was used as anticoagulant in blood.

\section{Hematological measures}

The blood samples were used for the estimation of total erythrocyte and leukocyte count with the help of using a Neubaur's counting haemocytometer following the methods given by Dacie \& Lewis. ${ }^{25}$

\section{Non-specific immune response}

Phagocytic assay and Phagocytic index: For phagocytic assay cells of freshly grown pathogenic bacteria Aeromonas hydrophila in 0.1 $\mathrm{ml}$ of PBS were added to $0.1 \mathrm{ml}$ of blood sample (pooled samples of blood of five fishes mixed with EDTA as anticoagulant) of fishes of each treatment in sterile microplate. Blood was then incubated for 30 $\min$ at $25^{\circ} \mathrm{C}$ after thorough mixing in the well. The plate was removed and fifty microlitres of each suspension was transferred on glass slides to make smears. After air drying, smear were fixed in $95 \%$ ethanol, re-dried and stained with May Grunwald Giemsa. The phagocytic 
cells and phagocytosed bacteria were enumerated. Phagocytic ratio (PR) and phagocytic index (PI) were determined by enumerating 100 phagocytes per slide under a microscope. The average of three slides was calculated depending on the formula which is given below.

Phagocytic ratio (PR; i.e. percentage of cell with engulfed bacteria $)=($ No. of phagocytic cells with engulfed bacteria/No. of phagocytic cells) $\times 100$.

Phagocytic index (PI; i.e. number of engulfed bacteria per cell $)=$ No. of engulfed bacteria/No. of phagocytic cells.

\section{Nitroblue tetrazolium (NBT) assay}

The oxygen radical production by phagocytes in blood during respiratory burst activity was measured through nitroblue tetrazolium (NBT) assay as described by Anderson \& Siwicki. ${ }^{26}$ Briefly, 0.1 $\mathrm{ml}$ of EDTA mixed blood from each treatment group was taken in Eppendorf to which $0.1 \mathrm{ml}$ of $0.2 \%$ NBT solution was added. The mixture was incubated for 30 minutes at $25^{\circ} \mathrm{C}$. From the suspension, $50 \mu \mathrm{l}$ was taken, added to $1.0 \mathrm{ml} \mathrm{N}, \mathrm{N}$-dimethyl formamide in a glass tube and centrifuged at $3000 \mathrm{~g}$ for 5 minutes. The optical density (OD) of the supernatant was measured at $540 \mathrm{~nm}$ in the spectrophotometer.

\section{Challenge test}

After feeding for 60 days, 10 fishes from each treatment were challenged with Aeromonas hydrohila which has been cultured and maintained in the selective medium. Fishes in all replicates immersed in a suspension of $A$. hydrophila $\sim 10^{5} \mathrm{CFU} \mathrm{ml}^{-1}$ followed by a second immersion $\sim 10^{7} \mathrm{CFU} \mathrm{ml}{ }^{-1}$ after 7 days. ${ }^{27}$ Per cent survival was measured for 10 days based on observation that mortality reached its plateau after 1 week $^{28}$ and relative percentage survival was calculated by the following formula ${ }^{29}$ RPS $=1$ - $($ Percent mortality in treated group/ Percent mortality in control group $) \times 100$

\section{Statistical analysis}

ANOVA followed by Duncan's multiple range test ${ }^{30}$ was applied to find out significant differences among dietary treatments Statistical significance was tested at a probability value of $\mathrm{P}<0.05$. The statistical tests were performed using SPSS Version 11.5 for Windows.

\section{Results}

\section{Effect of levamisole on growth and digestibility}

At the end of experiment, all groups receiving levamisole supplemented diets revealed significant increase in the body weight gain, specific growth rate (SGR), protein efficiency ratio (PER), gross conversion efficiency (GCE) and apparent protein digestibility (APD). A significant decrease in feed conversion ratio (FCR) in comparison with control group was found. These results are demonstrated in table (3) and figure (1). After 60 days, mean digestive enzyme activities of all levamisole treated groups were significantly different $(\mathrm{P}<0.05)$ with that of the control. The protease activity was remarkably higher $(\mathrm{P}<0.05)$ in L2 $(2.33 \pm 0.05)$ compared with control and other treatments. Amylase and cellulase, assays showed significantly higher $(\mathrm{P}<0.05)$ activity in treatment $\mathrm{L} 2$ fed fishes as compared to the rest.

\section{Effect of experimental diets on water quality characteristics}

The data on water quality characteristics pertaining to four dietary treatments is presented in table-4. In general, significantly $(\mathrm{P}<0.05)$ low values in total ammonia excretion and reactive phosphate production $\left(\mathrm{mg} \mathrm{Kg}^{-1} \mathrm{BW} \mathrm{d}^{-1}\right)$ were recorded in fish fed on diet L2. However, peak values of ammonia excretion occurred approximately $2 \mathrm{~h}$ after feed was given to fish and second peak at $8 \mathrm{~h}$ after feeding while o- $\mathrm{PO}_{4}$ production showed an initial high level at $4 \mathrm{~h}$ post feeding and second peak at $10 \mathrm{~h}$ post feeding (Fig-2A and 2B).

\section{Carcass composition}

After 60 days feeding trial initial and final carcass composition of Cirrhinus mrigala in relation to various feeds is presented in (Table 5). The carcass composition of the test animals revealed a significant $(\mathrm{P}<0.05)$ increase in the final carcass protein and lipid over the initial carcass protein and lipid. Significantly highest carcass protein $(16.4 \pm 0.20)$ and lipid $(7.46 \pm 0.2)$ was recorded in treatment L2 fed fishes as compare to other experimental and control feeds. However, no significant $(\mathrm{P}<0.05)$ variations were observed in crude ash $(\%)$ of carcass of fishes fed on different diets.

Table 3 Growth performances and intestinal enzyme activities of Cirrhinus mrigala fed on diets containing varying proportions of levamisole

\begin{tabular}{|c|c|c|c|c|}
\hline \multirow[b]{2}{*}{ Growth parameters } & \multicolumn{4}{|c|}{ Dietary treatments } \\
\hline & LC (control) & LI (I 25 mg) & L2 (250 mg) & L3 (500 mg) \\
\hline Initial weight $(\mathrm{g})$ & $\mathrm{I} .67 \pm 0.0 \mathrm{I}^{\mathrm{A}}$ & $1.68 \pm 0.016^{\mathrm{A}}$ & $1.69 \pm 0.02^{\mathrm{A}}$ & $1.69 \pm 0.02^{\mathrm{A}}$ \\
\hline Final weight $(\mathrm{g})$ & $4.39 \pm 0.06^{C}$ & $4.83 \pm 0.08^{B}$ & $5.44 \pm 0.08^{\mathrm{A}}$ & $5.00 \pm 0.09^{B}$ \\
\hline Live weight gain $(g)$ & $2.72 \pm 0.05^{c}$ & $3.15 \pm 0.10^{\mathrm{B}}$ & $3.75 \pm 0.06^{\mathrm{A}}$ & $3.31 \pm 0.07^{\mathrm{B}}$ \\
\hline Pre-challenge Survival rate (\%) & $96.00 \pm 2.60^{\mathrm{A}}$ & $100^{A}$ & $100^{\mathrm{A}}$ & $100^{A}$ \\
\hline Growth (\%) gain in BW & $162.50 \pm 3.18^{C}$ & $187.70 \pm 8.09^{B}$ & $222.00 \pm 2.19^{A}$ & $196.15 \pm 3.29^{B}$ \\
\hline Growth day $^{-1}(\%)$ in BW & $1.50 \pm 0.016^{C}$ & $1.6 \mathrm{I} \pm 0.03^{\mathrm{B}}$ & $1.75 \pm 0.08^{\mathrm{A}}$ & $1.65 \pm 0.0 I^{B}$ \\
\hline Specific growth rate (SGR) $\left(\% \mathrm{BW} \mathrm{d}^{-1}\right)$ & $0.69 \pm 0.008^{C}$ & $0.76 \pm 0.02^{B}$ & $0.84 \pm 0.004^{\mathrm{A}}$ & $0.78 \pm 0.008^{B}$ \\
\hline Feed conversion ratio (FCR) & $3.62 \pm 0.05^{\mathrm{A}}$ & $3.53 \pm 0.10^{\mathrm{AB}}$ & $3.10 \pm 0.08^{C}$ & $3.31 \pm 0.03^{B C}$ \\
\hline Gross conversion efficiency (GCE) & $0.27 \pm 0.003^{c}$ & $0.28 \pm 0.008^{B C}$ & $0.32 \pm 0.009^{A}$ & $0.30 \pm 0.003^{\mathrm{AB}}$ \\
\hline Protein efficiency ratio (PER) & $0.69 \pm 0.009 c$ & $0.70 \pm 0.02^{\mathrm{B}}$ & $0.80 \pm 0.02^{A}$ & $0.75 \pm 0.007^{A B}$ \\
\hline Apparent Protein Digestibility (\%) & $71.2 \pm 0.72^{\mathrm{C}}$ & $74.26 \pm 0.63^{\mathrm{B}}$ & $79.80 \pm 0.72^{\mathrm{A}}$ & $76.10 \pm 0.5 I^{B}$ \\
\hline Specific protease activity & $1.46 \pm 0.05^{C}$ & $1.68 \pm 0.02^{\mathrm{B}}$ & $2.33 \pm 0.05^{\mathrm{A}}$ & $1.78 \pm 0.05^{\mathrm{B}}$ \\
\hline Specific amylase activity ${ }^{2}$ & $1.2 \mathrm{I} \pm 0.02^{\mathrm{C}}$ & $1.29 \pm 0.03^{c}$ & $1.56 \pm 0.03^{A}$ & $1.43 \pm 0.02^{\mathrm{B}}$ \\
\hline Specific cellulase activity ${ }^{3}$ & $0.86 \pm 0.02^{\mathrm{D}}$ & $1.06 \pm 0.08 \mathrm{C}$ & $1.18 \pm 0.04^{A}$ & $0.90 \pm 0.04^{\mathrm{B}}$ \\
\hline
\end{tabular}

All values are Mean \pm S.E of mean

Img of tyrosine liberated $\mathrm{mg}$ of protein ${ }^{-1} \mathrm{~h}^{-1}$

$\mathrm{mg}$ of maltose liberated $\mathrm{mg}$ of protein ${ }^{-1} \mathrm{~h}^{-1}$

$3 \mathrm{mg}$ of glucose liberated $\mathrm{mg}$ of protein ${ }^{-1} \mathrm{~h}^{-1}$

Means with different letters in the same row are significantly $(P<0.05)$ different.

(Data were analyzed by Duncan's Multiple Range test) 
Table 4 Effect of fish fed with diet containing different proportion of levamsiole supplementation on water quality characteristics (Mean values of data analysed at fortnightly intervals)

\begin{tabular}{|c|c|c|c|c|}
\hline \multirow[t]{2}{*}{ Physiochemical Parameters } & \multicolumn{4}{|c|}{ Dietary Treatments } \\
\hline & LC (control) & LI (I 25 mg) & L2 (250 mg) & L3 (500 mg) \\
\hline Dissolved oxygen $\left(\mathrm{mgL}^{-1}\right)$ & $7.10 \pm 0.07^{A}$ & $6.85 \pm 0.07^{\mathrm{B}}$ & $6.77 \pm 0.05^{\mathrm{B}}$ & $7.22 \pm 0.05^{\mathrm{A}}$ \\
\hline $\mathrm{pH}$ & $7.7 I \pm 0.03^{\mathrm{A}}$ & $7.72 \pm 0.03^{\mathrm{A}}$ & $7.64 \pm 0.05^{\mathrm{A}}$ & $7.62 \pm 0.04^{\mathrm{A}}$ \\
\hline Conductivity $\left(\mu \mathrm{mho} \mathrm{cm}^{-1}\right)$ & $660.00 \pm 5.78^{B}$ & $654.00 \pm 3.5 \mathrm{I}^{\mathrm{A}}$ & $705.00 \pm 8.89^{A}$ & $713.00 \pm 5.18^{B}$ \\
\hline Temperature $\left({ }^{\circ} \mathrm{C}\right)$ & $25.70 \pm 0.33^{\mathrm{A}}$ & $26.90 \pm 0.54^{\mathrm{A}}$ & $28.00 \pm 0.35^{\mathrm{A}}$ & $27.80 \pm 0.32^{\mathrm{A}}$ \\
\hline Alkalinity & $145.00 \pm 2.08^{B}$ & $168.00 \pm 1.15^{\mathrm{A}}$ & $151.00 \pm 1.20^{\mathrm{B}}$ & $160.60 \pm 1.30^{A}$ \\
\hline Chloride( $\left.\mathrm{mg} \mathrm{L}^{-1}\right)$ & $30.60 \pm 0.83^{A}$ & $28.50 \pm 2.13^{\mathrm{A}}$ & $25.90 \pm 2.05^{A}$ & $27.16 \pm 2.17^{\mathrm{A}}$ \\
\hline Calcium $\left(\mathrm{mgL}^{-1}\right)$ & $22.32 \pm 0.74^{C}$ & $26.43 \pm 0.34^{\mathrm{B}}$ & $28.70 \pm 0.58^{\mathrm{A}}$ & $24.61 \pm 0.57^{\mathrm{BC}}$ \\
\hline Total dissolved solids & $601.00 \pm 11.54^{\mathrm{A}}$ & $584.00 \pm 9.08^{\mathrm{B}}$ & $546.00 \pm 8.15^{C}$ & $571.00 \pm 10.40^{\mathrm{BC}}$ \\
\hline Total ammonia excretion (mg Kg-1 BW day-1) & $1572.30 \pm 16.70^{A}$ & $1266.00 \pm 13.59^{B}$ & $906.00 \pm 10.09 D$ & $1064.00 \pm 13.56^{c}$ \\
\hline Total phosphate production (mg Kg-1 $\mathrm{BW}^{-1} \mathrm{yy}^{-1}$ ) & $645.00 \pm 9.93^{\mathrm{A}}$ & $608.30 \pm 10.10^{\mathrm{B}}$ & $526.00 \pm 13.13^{D}$ & $574.00 \pm 9.27^{c}$ \\
\hline
\end{tabular}

All values are Mean \pm S.E of mean.

Means with different letters in the same row are significantly $(P<0.05)$ different.

(Data were analyzed by Duncan's Multiple Range test)

Table 5 Proximate carcass composition of Cirrhinus mrigala fed on diets containing varying proportions of levamisole

\begin{tabular}{|c|c|c|c|c|c|}
\hline \multirow{2}{*}{$\begin{array}{l}\text { Proximate } \\
\text { composition }\end{array}$} & \multirow[b]{2}{*}{ Initial value } & \multicolumn{2}{|c|}{ Dietary treatments } & \multirow[b]{2}{*}{ L2 (250 mg) } & \multirow[b]{2}{*}{ L3 (500 mg) } \\
\hline & & LC (control) & LI (I 25 mg) & & \\
\hline Moisture (\%) & $70.00 \pm 0.53$ & $68.40 \pm 0.45^{\mathrm{A}}$ & $67.10 \pm 0.28^{B}$ & $64.70 \pm 0.35^{c}$ & $65.60 \pm 0.23^{c}$ \\
\hline Crude protein (\%) & $10.40 \pm 0.38$ & $11.62 \pm 0.18^{D}$ & $|4.9| \pm 0.46^{B}$ & $16.40 \pm 0.20^{A}$ & $13.20 \pm 0.35^{c}$ \\
\hline Crude fat (\%) & $5.31 \pm 0.18$ & $5.80 \pm 0.15^{c}$ & $6.7 I \pm 0.14^{\mathrm{B}}$ & $7.46 \pm 0.20^{A}$ & $7.38 \pm 0.07^{A}$ \\
\hline Crude ash (\%) & $2.25 \pm 0.14$ & $3.50 \pm 0.1 I^{\mathrm{A}}$ & $3.0 \mathrm{I} \pm 0.30^{\mathrm{AB}}$ & $2.83 \pm 0.16^{\mathrm{C}}$ & $2.93 \pm 0.22^{\mathrm{BC}}$ \\
\hline Nitrogen free extract (\%) & $12.03 \pm 0.22$ & $10.68 \pm 0.4 I^{A}$ & $8.25 \pm 0.52^{B}$ & $8.16 \pm 0.48^{B}$ & $10.88 \pm 0.29^{A}$ \\
\hline Gross energy (kJ/g) & $6.36 \pm 0.12$ & $7.05 \pm 0.03^{c}$ & $7.90 \pm 0.05^{\mathrm{B}}$ & $8.37 \pm 0.05^{A}$ & $7.80 \pm 0.1 I^{B}$ \\
\hline Phosphorous (\%) & $0.54 \pm 0.01$ & $0.5 \mathrm{I} \pm 0.05^{\mathrm{C}}$ & $0.59 \pm 0.03^{C}$ & $0.65 \pm 0.012^{\mathrm{B}}$ & $0.73 \pm 0.02^{\mathrm{A}}$ \\
\hline
\end{tabular}

All values are Mean \pm S.E of mean.

Means with different letters in the same row are significantly $(P<0.05)$ different.

(Data were analyzed by Duncan's Multiple Range test)

Table 6 Haematological parameters of Cirrhinus mrigala fed on diet containing various proportions of levamisole

\begin{tabular}{lllll}
\hline & \multicolumn{2}{l}{ Haematological Parameters } & TLC $\left(10^{3} \mathbf{m m}^{3}\right)$ \\
Treatments & $\begin{array}{l}\text { TEC }\left(10^{6} \mathbf{m m}^{3}\right) \\
\text { Pre Challenge }\end{array}$ & Post Challenge & Pre challenge & Post Challenge \\
\hline LC (control) & $1.22 \pm 0.0^{\mathrm{D}}$ & $1.08 \pm 0.015^{\mathrm{D}}$ & $22.06 \pm 0.73^{\mathrm{D}}$ & $23.46 \pm 0.35^{\mathrm{D}}$ \\
LI $(150 \mathrm{mg})$ & $1.48 \pm 0.0^{\mathrm{C}}$ & $1.31 \pm 0.016^{\mathrm{C}}$ & $31.76 \pm 0.62^{\mathrm{C}}$ & $37.03 \pm 0.64^{\mathrm{C}}$ \\
L2 $(250 \mathrm{mg})$ & $1.93 \pm 0.0^{\mathrm{A}}$ & $1.80 \pm 0.04^{\mathrm{A}}$ & $51.26 \pm 0.63^{\mathrm{A}}$ & $54.32 \pm 0.64^{\mathrm{A}}$ \\
L3 $(500 \mathrm{mg})$ & $1.66 \pm 0.0^{\mathrm{B}}$ & $1.55 \pm 0.02^{\mathrm{B}}$ & $40.76 \pm 0.96^{\mathrm{B}}$ & \\
\hline
\end{tabular}

TEC:Total erythrocyte count

TLC:Total leucocyte count

Means with different letters in the same column are significantly $(P<0.05)$ different.

(Data were analyzed by Duncan's Multiple Range test)

\section{Haematological Parameters (Total Erythrocyte and Leukocyte Count)}

Levamsiole incorporation in C. mrigala diet in present studies resulted in elevated level in total erythrocyte and total leucocyte count. The Total erythrocyte count was significantly higher $(\mathrm{P}<0.05)$ in fishes fed on diet L2 $(1.93 \pm 0.04)$ than in the control treatment LC $(1.22 \pm 0.01)$. Also, significant increase $(\mathrm{P}<0.05)$ in $\mathrm{WBC}$ count was observed in fishes of treatment L2 $(51.26 \pm 0.63)$ than in control treatment LC (22.06 \pm 0.73$)$ (Table 6). However, erythrocyte count declined while TLC increased in the levamisole treated group in the after a challenge trial as compared to control.

\section{Phagocytic responses}

Phagocytic activity (PA) and phagocytic index (PI) of fish fed garlic diets were significantly higher than those of fish fed the control diet for 60 days (Table 7). The relative PA and PI levels (compared to the control group) of fish fed diets L1, L2 and L3 for 60 days increased by $64.3 \pm 3.75 \%$ and $1.68 \pm 0.07 \% ; 80.31 \pm 0.96 \%$ and $2.35 \pm 0.03 \%$; $72.40 \pm 1.62 \%$ and $1.76 \pm 0.05 \%$, respectively.

\section{NBT assay or Respiratory burst activity}

The respiratory burst activities of cell in treated increased significantly $(\mathrm{P}<0.05)$ compared with the control fish (Table 8). Maximum increase in the NBT reduction value was observed in treatment L2 containing levamisole @ 250 mg kg-1 of diet. 
Table 7 Effect of levamisole and their interaction on Phagocytic ratio and Phagocytic index (\%) of Cirrhinus mrigala

\begin{tabular}{|c|c|c|c|c|c|}
\hline \multicolumn{6}{|c|}{ Peripheral Blood Monocytes } \\
\hline $\begin{array}{l}\text { Phagocytic } \\
\text { index }\end{array}$ & $\begin{array}{l}\text { Phagocytic ratio } \\
\text { (\%) }\end{array}$ & $\begin{array}{l}\text { Bacteria within } \\
\text { phagocytes }\end{array}$ & $\begin{array}{l}\text { No. of ingested } \\
\text { phagocytes }\end{array}$ & $\begin{array}{l}\text { Total no. of } \\
\text { phagocytes }\end{array}$ & Treatments \\
\hline $1.54 \pm 0.06^{C}$ & $60.63 \pm 1.27^{C}$ & $107.00 \pm 7.37^{C}$ & $42.00 \pm 1.53^{c}$ & $69.30 \pm 2.96^{c}$ & LC (control) \\
\hline $1.68 \pm 0.07^{c}$ & $64.35 \pm 3.75^{c}$ & $127.00 \pm 9.6^{C}$ & $48.30 \pm 2.18^{c}$ & $75.30 \pm 3.18^{B}$ & LI (I50 mg) \\
\hline $2.35 \pm 0.03^{\mathrm{A}}$ & $80.31 \pm 0.96^{A}$ & $218.60 \pm 4.06^{\mathrm{A}}$ & $74.60 \pm 1.76^{A}$ & $93.00 \pm 2.52^{\mathrm{A}}$ & L2 (250 mg) \\
\hline $1.76 \pm 0.05^{\mathrm{B}}$ & $72.40 \pm 1.62^{\mathrm{B}}$ & $160.30 \pm 8.38^{B}$ & $66.00 \pm 2.89^{B}$ & $91.00 \pm 2.08^{\mathrm{A}}$ & L3 (500 mg) \\
\hline
\end{tabular}

Means with different letters in the same column are significantly $(P<0.05)$ different.

(Data were analyzed by Duncan's Multiple Range test)

Table 8 The respiratory burst activity of Cirrhinus mrigala fed on diet containing various proportions of levamisole

\begin{tabular}{lll}
\hline S. No. & Treatments & The respiratory burst activity (O.D. at 540 nm) \\
\hline$I$ & LC (control) & $0.39 \pm 0.0 \mathrm{I}^{\mathrm{D}}$ \\
2 & $\mathrm{LI}(\mathrm{I} 50 \mathrm{mg})$ & $0.48 \pm 0.0 \mathrm{I}^{\mathrm{C}}$ \\
3 & $\mathrm{~L} 2(250 \mathrm{mg})$ & $0.7 \mathrm{I} \pm 0.0 \mathrm{I}^{\mathrm{A}}$ \\
4 & $\mathrm{~L} 3(500 \mathrm{mg})$ & $0.55 \pm 0.02^{\mathrm{B}}$ \\
\hline
\end{tabular}

Means with different letters in the same column are significantly $(P<0.05)$ different.

(Data were analyzed by Duncan's Multiple Range test)

\section{Relative percentage survival after challenge test}

The challenge test for 10 days was performed after the feeding trial revealing that long term oral administration of levamisole supplemented feed enhanced the resistance of Cirrhinus mrigala to bacterial infection (Table 9). Water quality parameters were analysed on day one and day 5 of challenge trial. No significant variations were observed hence data not shown. After challenge with Aeromonas hydrophila, the first mortality was recorded after $48 \mathrm{~h}$. Significantly higher $(\mathrm{P}<0.05)$ post-challenge survival rates were observed in the fish groups fed diets containing levamisole @ $250 \mathrm{mg} \mathrm{kg}^{-1}$ of feed (86.35\%) followed by L3 (50.06\%) and L1 (31.78\%) while the fish fed with control diet exhibited the highest mortality $(73.3 \pm 6.67 \%)$. However, pre-challenge survival rate (\%) during the feeding trial was high in all dietary treatments and slight mortality occurred only during the initial days of experiment.

Table 9 Percentage mortality and Relative Per cent Survival (RPS) of Cirrhinus mrigala in a challenge trial with Aeromonas hydrophila for 10 days

\begin{tabular}{llll}
\hline S. No. & Treatments & $\begin{array}{l}\text { Percentage } \\
\text { Mortality (\%) }\end{array}$ & $\begin{array}{l}\text { Relative Percent } \\
\text { Survival (\%) }\end{array}$ \\
\hline I & LC (control) & $73.30 \pm 6.67^{\mathrm{A}}$ & \\
2 & LI (I50 mg) & $50.00 \pm 5.78^{\mathrm{B}}$ & 31.78 \\
3 & L2 (250 mg) & $10.00 \pm 5.78^{\mathrm{C}}$ & 86.35 \\
4 & L3 (500 mg) & $36.60 \pm 3.33^{\mathrm{B}}$ & 50.06 \\
\hline
\end{tabular}

Means with different letters in the same column are significantly $(P<0.05)$ different.

(Data were analyzed by Duncan's Multiple Range test)

\section{Discussion}

The growth trial conducted in present study showed significantly $(P<0.05)$ enhanced growth and feed efficiency (in terms of SGR, PER, GCR, APD, etc) of C. mrigala after 60 days of consuming the diet with different concentration of levamisole. Maqsood et al. ${ }^{10}$ also reported that upon dietary levamisole supplementation $(250 \mathrm{mg}$ levamisole Kg-1 of diet) the growth parameters of Cyprinus carpio were significantly enhanced when compared with the fish fed on control diet. Similar findings were reported by Misra et al. \& Mulero et al. ${ }^{31-33}$ for gilthead seabream reported that the dietary intake of levamisole had a significant impact on the size and weight of fish throughout the experiment when compared with control. In a study by Li et al. ${ }^{34}$ on juvenile hybrid striped bass, low doses of levamisole $(<500 \mathrm{mg}$ $\mathrm{kg}^{-1}$ of diet) significantly enhanced feed efficiency and growth by approximately $10 \%$ after 3 weeks of feeding as compared to fish fed on basal diets. In the present study $37.86 \%$ increase in growth has been observed by feeding the fish on levamisole (@250 mg kg-1) supplemented diets in comparison to controls. From these results it could be said that levamisole has potent growth promoting effect and may act as alternative approach to enhance fish health.

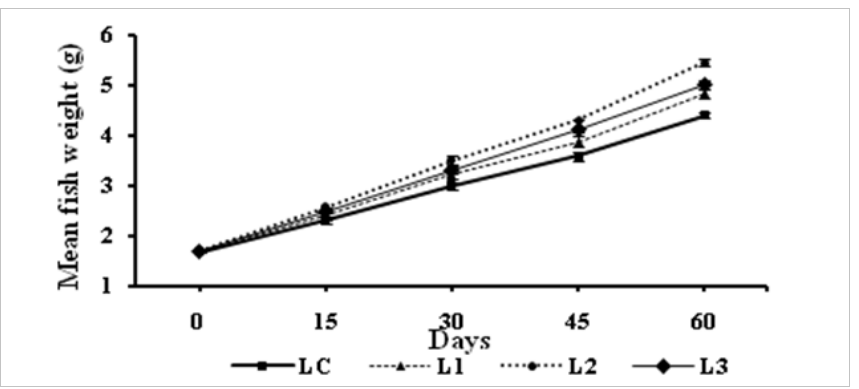

Figure I Increase in mean fish weight (g) (Mean \pm S.E of mean) of Cirrhinus mrigala fed on diets supplemented with varying proportions of levamisole ( $L C=$ control, $L I=125 \mathrm{mg}, \mathrm{L} 2=250 \mathrm{mg}$ and $\mathrm{L} 3=500 \mathrm{mg}$ of diet) from day 15 to 60 .

In aquaculture, water quality deteriorates mainly due to accumulation of metabolic wastes such as ammonia and orthophosphate excretion in the holding water. In the present studies the excretion of

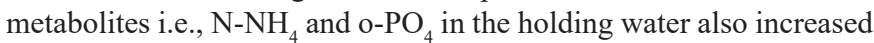
with the increase in the inclusion level of levimasole dose. This may again be attributed to low feed utilization and when dietary utilization is low, deamination of unutilized feed protein occurs and excretion of metabolites in the holding water increases above the optimum. Thus when the value of the immunostimulant exceeds the optimum limit, there is negative impact on nutritive physiology decreasing growth performance and increasing excretion of metabolites in holding water.

Our result clearly indicates the enhancement in certain carcass composition in all immunostimulants treated fishes. Perhaps high nutrient value in carcass was due to the increased enzymatic activity 
in the gut and there by nutrients was utilized properly and spends for the growth making overall well-being for the fishes.
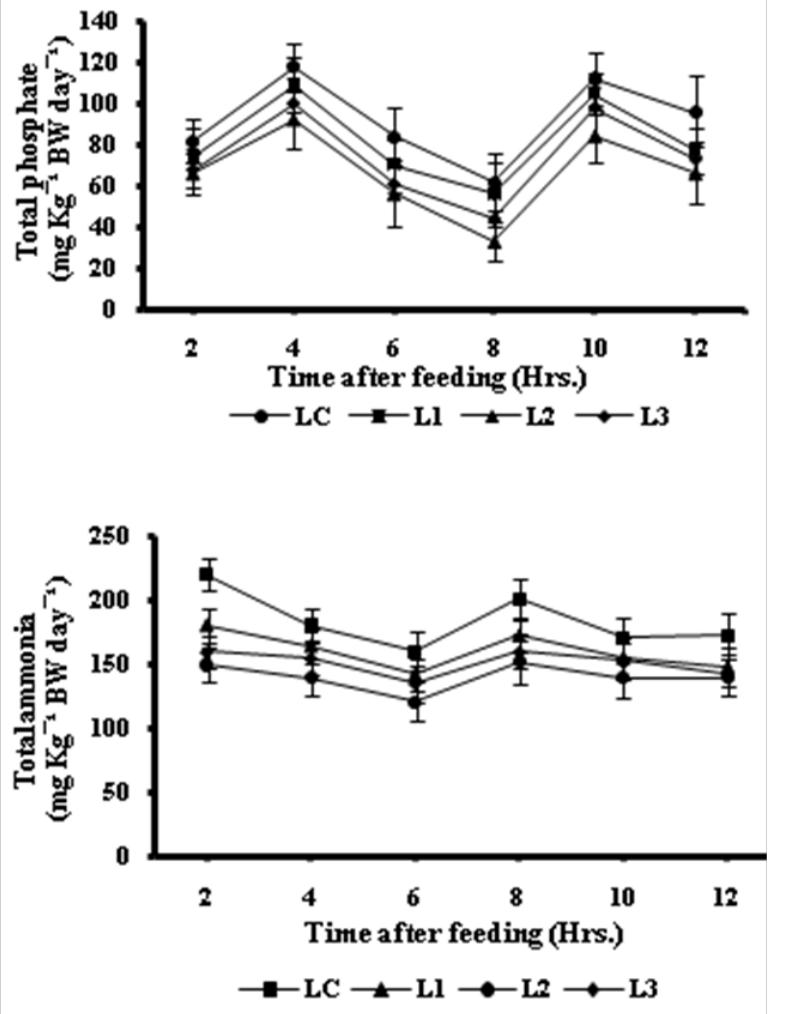

Figure 2 Post prandial excretory patterns of orthophosphate $(2 A)$ and total ammonia (2B), $\left(\mathrm{mg} \mathrm{kg}^{-1}\right.$ body weight per day of fish) in holding water for fish Cirrhinus mrigala in different dietary treatments containing varying proportion of levamisole ( $\mathrm{LC}=$ control, $\mathrm{LI}=125 \mathrm{mg}, \mathrm{L} 2=250 \mathrm{mg}$ and $\mathrm{L} 3=500$ $\mathrm{mg}$ of diet).

Levamsiole incorporation in C. mrigala diet in present studies resulted in elevated level in total erythrocyte and total leucocyte count. However, erythrocyte count declined after challenge with pathogen may be due to effect of pathogen but this effect was least in the fishes where levimasole was used at optimum dose corresponding significantly with other immune response parameters indicating that supplementation of levimasole at optimum levels can significantly reduce the effect of pathogen. These findings are in agreement with that of Bruno and Munro ${ }^{35}$ who reported that the experimental infection of rainbow trout and Atlantic salmon with Renibacterium salmoninarum and the subsequent progression of Bacterial Kidney Disease (BKD) resulted in the significant decline in TEC levels. Similar findings were also reported by Mulero et al. Kumari \& Sahoo. ${ }^{33,9-11}$ Likewise, there was an increase in TLC in the levamisole treated group in the after a challenge trial as compared to control which could be attributed to the activation of immune response against the bacterial invasion which was significantly $(\mathrm{P}<0.05)$ high in fish group fed on diet containing levamisole in the proportion of $250 \mathrm{mg}$ $\mathrm{kg}^{-1}$ of diet. Similar findings of significantly enhanced total leucocyte level in carp fed with levamisole @ $250 \mathrm{mg} \mathrm{kg}^{-1}$ when compared to control were reported by Maqsood et al. \& Misra et al. ${ }^{11}$ also observed significantly $(\mathrm{P}<0.05)$ high WBC count in fish administered with low and medium dosages of levamisole when compared to control group.
Many studies have reported capability of levamisole in enhancing immune responses and/or reducing losses from bacteria and/or parasitic infections in different species such as carp, ${ }^{8,10}$ gilthead sea bream, ${ }^{33}$ rainbow trout, ${ }^{14,36}$ Atlantic salmon, ${ }^{37,38}$ rohu, ${ }^{39,40,11}$ hybrid striped bass, ${ }^{34}$ catfish. ${ }^{12}$

Levamisole induced significant $(\mathrm{P}<0.05)$ increase in blood phagocytic activities in all treatment groups as compared to control in the present studies. Wijendra \& Pathiratne ${ }^{40}$ also observed significantly elevated levels of total phagocytic activity, phagocytic index in levamisole treated Labeo rohita compared to that of the respective control fish post 21 days of treatment. Similar results were obtained by Ispir \& Yonar $^{36}$ in Rainbow Trout (Oncorhynchus mykiss) where fish exposed to different concentrations of levamisole showed significantly higher activity of phagocytic cells than that in controls. Kajita et al. ${ }^{41}$ in a study observed that activation of alternative complement pathway by levamisole may attribute to enhanced phagocytosis, chemiluminescence responses and natural killer cell activity in rainbow trout, Oncorhynchus mykiss (Walbaum). Misra et al. ${ }^{11}$ also found significant $(\mathrm{P}<0.05)$ increase in phagocytic ratio in different treatment groups of Labeo rohita up to 42nd day of immunomodualtion trial. On all the assay days, it was marked that medium dose of levamisole could result in higher phagocytic ratio compared to other group of fish. In our study too, maximum phagocytic activity was reported in L2 fed group containing levamisole @ $250 \mathrm{mg}$ $\mathrm{kg}^{-1}$ clearly indicating a dose dependent response of immunostimulant levimasole.

Phagocytes produce huge quantities of superoxide anion during phagocytosis or upon stimulation which can be reduced by NBT. The NBT reduction product obtained after reaction with superoxides is hence a good indicator of the health status or the immunization effectiveness in fish Anderson et al. ${ }^{42}$ which was also observed in present study. Similar results were obtained by Gopalakannan \& Arul $^{32}$ for Cyprinus carpio. Kumari \& Sahoo $^{9}$ also reported significantly high respiratory burst (NBT) activity in levamisole fed group as compared to the CYP-treated control group. Rairakhwada et al. ${ }^{43}$ also showed that the NBT values for levamisole fed fish were higher when compared with the control fish. A higher NBT activity was detected in Puntius gonionotus (Japanese carp) following injection with $A$. hydrophila ${ }^{44}$ Sharp \& Secombes ${ }^{45}$ suggested that increased respiratory burst activity can be correlated with increased bacterial pathogen killing activity of phagocytes.

A high survival rate was reported on levamisole treated fish group after a 10 day challenge with pathogenic A. hydrophila. Similar findings were reported by Gopalakannan \& Arul ${ }^{32}$ after challenge trial of immunostimulant supplemented feed fed Cyprinus carpio with Aeromonas hydrophila. Baba et al. ${ }^{8}$ also reported that survival rate after challenging the fish with Aeromonas hydrophila was higher in common carp treated with levamisole. Levamisole has also been found to be a possible modulator of the immune response by eliciting resistance after challenge trial in Cyprinus carpio $^{46,8}$ Oncohrynchus mykiss, ${ }^{42}$ Sparus aurata, ${ }^{33}$ Clarias batrachus, ${ }^{9}$ Morone chrysops $\times$ Morone saxatilis. ${ }^{34}$

\section{Conclusion}

Results of the present investigation reveal that a dose of $250 \mathrm{mg}$ levamisole $\mathrm{kg}^{-1}$ diet is optimum to stimulate the immune function of Cirrhinus mrigala same dose oflevamisole was equally effective in stimulating thegrowth. However efficacy of levamisole and its study on cellular and molecular mechanisms is subject for further research. 


\section{Acknowledgments}

None.

\section{Conflicts of interest}

None.

\section{References}

1. Anderson DP. Immunostimulants, adjuvants, and vaccine carriers in fish: applications to aquaculture. Annu Rev Fish Dis. 1992;2:281-307.

2. Bairwa MK, Jakhar JK, Satyanarayana Y, et al. Animal and plant originated immunostimulants used in aquaculture. Journal of Natural Product and Plant Resources. 2012;2(3):397-400.

3. Renoux G. The general immunopharmocology of levamisole. Drugs 1980;20(2):89-99.

4. Morimoto $\mathrm{C}$, Abe T, Homma M. Restoration of T-cell function in aged mice with long-term administration of levamisole. Clin Immunol Immunopathol. 1979;12(3):316-322.

5. Ogunbiyi PO, Conlon PD, Black WD, et al. Levamisole-induced attenuation of alveolar macrophage dysfunction in respiratory virusinfected calves. Int J Immunopharmacol. 1988;10(4):377-385.

6. Kimball ES, Fisher MC. Levamisole effects on major histocompatibility complex and adhesion molecule expression and on myeloid cell adhesion to human colon tumor cell lines. J Natl Cancer Inst. 1996;88(2):109116.

7. Siwicki AK. Immunomodulating activity of levamisole in carp spawners, Cyprinus carpio L. Journal of Fish Biology. 1987;31: 245246.

8. Baba T, Watase Y, Yoshinaga Y. Activation of mononuclear phagocyte function by levamisole immersion in carp. Nippon Suisan Gakk. 1993;59(2):301-307.

9. Kumari S, Sahoo PK. Dietary levamisole modulates the immune response and disease resistance of Asian catfish Clariasbatrachus (Linnaeus). Aquacult Res. 2006;37(5):500-509.

10. Maqsood S, Samoon MH, Singh P. Immunomodulatory and growth promoting effect of dietary levamisole in Cyprinuscarpioagainst the challenge of Aeromonas hydrophila.Turk J Fish Aquat Sci. 2009;9:111120.

11. Misra CK, Das BK, Mukherjee SC. Immune response, growth and survival of Labeo rohita fed with levamisole supplemented diets for longer duration. Aquacult Nutr. 2009;15(4):356-365.

12. Aly S, Abd-Allah O, Mahmoud A, et al. Efficiency of levamisole in improving the immune response of Catfish (ClariasGariepenus) to Aeromonas hydrophila vaccine: Clinico-Pathological Studies. Mediterranean Aquaculture Journal. 2010;1(1):8-17.

13. Anderson DP, Jeney G. Immunostimulants added to injected Aeromonas salmonicida bacterin enhances the defense mechanisms and protection in rainbow trout (Oncorhynchus mykiss). Vet Immunol Immunopathol. 1992;34(3-4):379-389.

14. Jeney G, Anderson DP. Enhanced immune response and protection in rainbow trout to Aeromonassalmonicida bacterin following prior immersion in immunostimulants. Fish Shellfish Immunol. 1993;3(1):5158 .

15. Maqsood S, Singh $\mathrm{P}$, Samoon $\mathrm{MH}$, et al. Emerging role of immunostimulants in combating the disease outbreak in aquaculture. Int Aquat Res. 2011;3:147-163.

16. AOAC (Association of Official Analytical Chemists), Official methods of analysis. Association of Official Analytical Chemists Incorporation. Arlington, USA. 1995;pp.684.
17. Furukawa A, Tuskahara $\mathrm{H}$. On the acid digestion method for the determination of chromic oxide as an index substance in the study of digestibility of fish feed. Bulletin of Japanese Society for the Science of fish. 1966;32(6):502-506.

18. Cho CY, Slinger SJ, Bayley HS. Bioenergetics of salmonid fishes: energy intake, expenditure and productivity. Comp Biochem PhysB. $1982 ; 73(1): 25-41$.

19. Steffens W. Principles of fish nutrition. Horwood, Chichester, UK 1989;pp.384.

20. Walter HE. Probionases : Methods with haemoglobin, casein and azocoll as substrates, In Bergmeyer HU(Ed.), Methods of Enzymatic Analysis, Verlag Chemic, Weinheim. 1984;pp.270-277.

21. Sawhney SK, Singh R. Introductory Practical Biochemistry. Narosa Publishing House, pp.2000;452.

22. Sadasivam S, Manickam A. Biochemical methods. New Age International Publishers, New Delhi, India. 1996

23. APHA. Standard methods for the examination of water and waste water. (20th edn), American Public Health Association, New York. 1998;pp.80-164.

24. Sumagaysay-Chavoso NS. Nitrogen and phosphorus digestibility and excretion of different size groups of milkfish (Chanos chanosForsskal) for formulated and natural food based diets. Aquacult Res. 2003;34(5):407-418.

25. Dacie SIV, Lewis SM. Practical Haematology. J and A. Churchill Ltd., Livington, London, Melbourne and New York. 1971;pp.96.

26. Anderson DP, Siwicki AK. Basic haematology and serology for fish health programs. In: Shariff M, Subasinghe JRP (Eds.), Diseases in Asian Aquaculture II. Fish Health Section, Asian Fisheries Society, Manila, Philippines. 1995;pp.185-202.

27. Austin B, Stuckey LF, Robertson PAW, et al. A probiotic strain of Vibrio alginolyticus effective in reducing diseases caused by Aeromonas salmonicida, Vibrio anguillarum and Vibrio ordalii. J Fish Dis. 1995;18(1):93-96.

28. Sahoo PK, Mukherjee SC, Sahoo SK. Aeromonas hydrophilaversus Edwardsiella tarda: a pathoanatomical study in Clarias batrachus. Journal of Aquaculture. 1998;6:57-66.

29. Ellis AE. Fish Vaccination. Academic Press, London. 1988;pp.84.

30. Duncan DB. Multiple range and multiple F-tests. Biometrics. $1955 ; 11(1): 1-42$.

31. Misra CK, Das BK, Mukherjee SC, et al. Effect of long term administration of dietary Beta-glucan on immunity, growth and survival of Labeo rohita fingerling. Aquaculture. 2005;255(1-4):82-94.

32. Gopalakannan A, Arul V. Immunomodulatory effects of chitin, chitosan and levamisole on the immune system of Cyprinus carpio and control of Aeromonas hydrophila infection in ponds. Aquaculture. 2006;255(14):179-187

33. Mulero V, Esteban MA, Munoz J, et al. Dietary intake of levamisole enhances the immune response and disease resistance of the marine teleost gilthead seabream (Sparus aurata L). Fish Shellfish Immun. 1998;8(1):49-62.

34. Li G, Guo Y, Zhao D, et al. Effects of levamisole on the immune response and disease resistance of Clarias fuscus. Aquaculture. 2006;253(14):212-217.

35. Bruno DW, Munro ALS. Haematological assessment of rainbow trout, Salmo gairdneri Richardson, and Atlantic salmon, Salmo salar L., infected with Renibacterium salmoninarum. J Fish Dis. 1986;9(3):195204. 
36. Ispir U, Yonar ME. Effects of Levamisole on phagocytic activity of Rainbow Trout (Oncorhynchus mykiss W.) Acta Veterinaria Brno. 2007;76(3):493-497.

37. Findlay VL, Zilberg D, Munday BL. Evaluation of levamisole as a treatment for amoebic gill disease of Atlantic salmon, Salmo salar L. J Fish Dis. 2000;23(3):193-198.

38. Morrison RN, Nowak BF, Carson J. The histopathological effects of a levamisole-adjuvanted Vibrioanguillarum vaccine on Atlantic salmon (Salmo salar L.). Aquaculture. 2001;195(1-2):23-33.

39. Sahoo PK, Mukherjee SC. The effect of dietary immunomodulation upon Edwardsiellatarda vaccination in healthy and immunocompromised Indian major carp (Labeo rohita). Fish Shellfish Immunol. 2002;12(1):116.

40. Wijendra GDNP, Pathiratne A. Evaluation of immune responses in an Indian carp, Labeo rohita(Hamilton) fed with levamisole incorporated diet. Journal of Science University of Kelaniya. 2007;3:17-28.

41. Kajita Y, Sakai M, Atsuta S, et al. The immunomodulatory effects of levamisole on rainbow trout, Oncorhynchusmykiss. Fish Pathol. 1990;25(2):93-98.
42. Anderson DP, Moritomo T, de Grooth R. Neutrophil, glass-adherent, nitro blue tetrazolium assay gives early indication of immunization effectiveness in rainbow trout. Vet Immunol Immunopathol. 1992;30(4):419-429.

43. Rairakhwada D, Pal AK, Bhathena ZP, et al. Dietary microbial levan enhances cellular non-specific immunity and survival of common carp (Cyprinus carpio) juveniles. Fish Shellfish Immunol. 2007;22(5):477486

44. Shariff M, Jayawardena PA, Yusoff FM, et al. Immunological parameters of Japanese carp Puntius gonionotus (Blecker) exposed to copper and challenged with Aeromonas hydrophila. Fish Shellfish Immunol. 2001;11(4):281-291.

45. Sharp GJE, Secombes CJ. The role of reactive oxygen species in the killing of the bacterial fish pathogen Aeromonassalmonicidaby rainbow trout macrophages. Fish Shellfish Immunol. 1993;3(2):119-129.

46. Siwicki AK. Immunomodulating influence of levamisole on nonspecific immunity in carp (Cyprinus carpio). Dev Comp Immunol. 1989;13:87-91. 